\title{
自家海綿骨で再建を行った鼻口蓋管囊胞例
}

\author{
河田 恭孝1)・河田＼cjkstart桂2) ・ 藤木 暢也 ${ }^{3)}$ \\ 塩見 洋作 ${ }^{4)} \cdot$ 倉田 響介 ${ }^{3)}$
}

\section{A Case of Nasopalatine Duct Cyst Reconstructed with Autogenous Cancellous Bone}

\author{
Yasutaka Kawata \\ (Tenri Hospital) \\ Katsura Kawata \\ (Kitano Hospital) \\ Nobuya Fujiki and Kyosuke Kurata \\ (Kyoto University) \\ Yosaku Shiomi \\ (Matsue Municipal Hospital)
}

\begin{abstract}
Nasopalatine duct cyst is a nonodontogenic cyst that arises from the remains of the nasopalatine duct. It is comparatively rare among all cysts of the maxilla.

A 29-year-old male visited our clinic because of an increasing anterior midline palatal mass. MR imaging showed a large cystic lesion, which was $32 \mathrm{~mm}$ in diameter, arising within the nasopalatine duct. After removal of the cyst, a large dead space remained. It was reconstructed with autogenous cancellous bone of the iliac crest. At the time of 6 months after the surgery, 3 dimensional CT demonstrated good contour of the palatal bone. Autogenous cancellous bone is very useful and reliable material for the reconstruction of palatal bone defects.
\end{abstract}

Key words : nasopalatine duct cyst, cancellous bone, reconstruction, palatal bone defect

はじめに

鼻口蓋管襄胞は上顎正中部に生じる非歯原性囊胞の一 つで，鼻口蓋管の上皮遺残に由来するとされ1)，その発 生は比較的まれとされている2). 今回われわれは，摘出 後に生じた組織欠損を自家海綿骨で再建した症例を経験 した. 本疾患の文献的考察と今回の手術手技について報 告する.

\section{症例 : 29歳, 男性.}

症例

主訴 : 上㴿正中部の腫脹.

現病歴: 平成 8 年 1 月, 硬口蓋正中前方に腫脹がある のに気付いたが，痛みを伴わないため放置していた，そ の後も腫脹が縮小しないため, 近医を受診し, MRIに て腫瘤陰影を指摘され, 平成 8 年 5 月 30 日当科紹介受診 となった。

既往歴：歯科治療の既往なし。
1）天理よろづ相談所病院耳鼻咽喉科

3）京都大学医学部附属病院耳鼻咽喉科
2) 北野病院耳鼻咽喉科

4）松江市立病院耳鼻咽喉科 


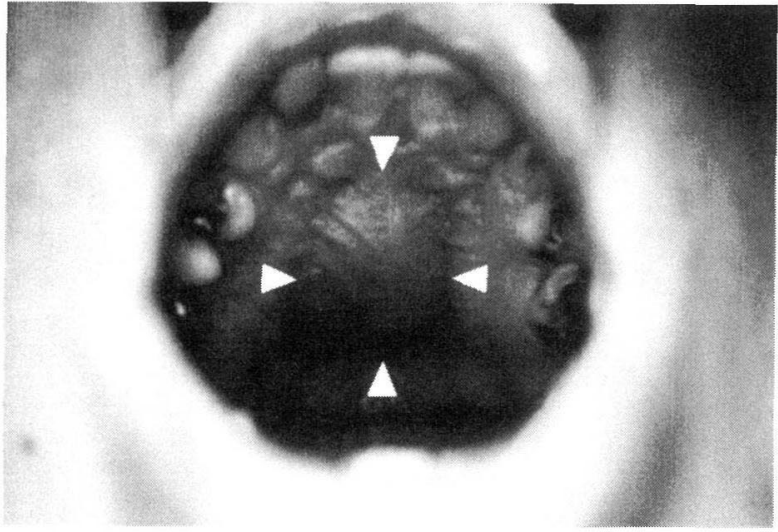

図 1 口腔内所見

硬口蓋前方正中に, 半球状の腫脹を認める, 一部に骨欠 損があり，波動を触知した。

家族歴：特記すべきことなし。

口腔内所見：硬口蓋前方正中部に直径 $32 \mathrm{~mm}$ の半球 状の腫脹を認めた。压痛，疼痛は認めず，中心部は骨欠 損を認め波動索触知した(図 1 )。
MRI 所見：硬口蓋正中に，T1，T2強調ともに高信 号を示す辺縁整の陰影を認め, 蛋白濃度の高い液の貯留 した囊胞性病变が疑われた(図 2 ). 平成 8 年10月17日に 手術を施行した。

手術所見：全身麻酔下に歯龈部切開を行い，腫瘍前方 で粘膜骨膜升学上したところ, 歯槽骨は欠損し, 前鼻 棘, 鼻中隔前端も消失していた。霊胞壁は鼻腔底粘膜と の癒着が認められ，剥離が困難であったため，鼻腔底粘 膜の一部とともに切除し，その欠損は縫縮した． 口蓋粘 膜との癒着は軽度で㐫ったが，口蓋骨鼻腔側の骨皮質は 消失していた。蓋骨口腔側の骨皮質は一部消失し，そ の周囲は菲薄化していた。また，歯根尖の囊胞腔への突 出は認めなかった。䪄胞は表面平滑で, 内容物は暗褐色 の粘液性の液体であった，摘出後，同部に $30 \times 15 \mathrm{~mm}$ の死腔が残存したため，右前上腸骨稜の骨皮質を扉状に 開き，海綿骨のみを採取し(図 3)，これを細かく砕いた 後, フィブリン糊を混合してペースト状とし，死腔に充 填した.

術後経過: 術後 6 カ月の 3D-CT では(図 4), 海綿骨

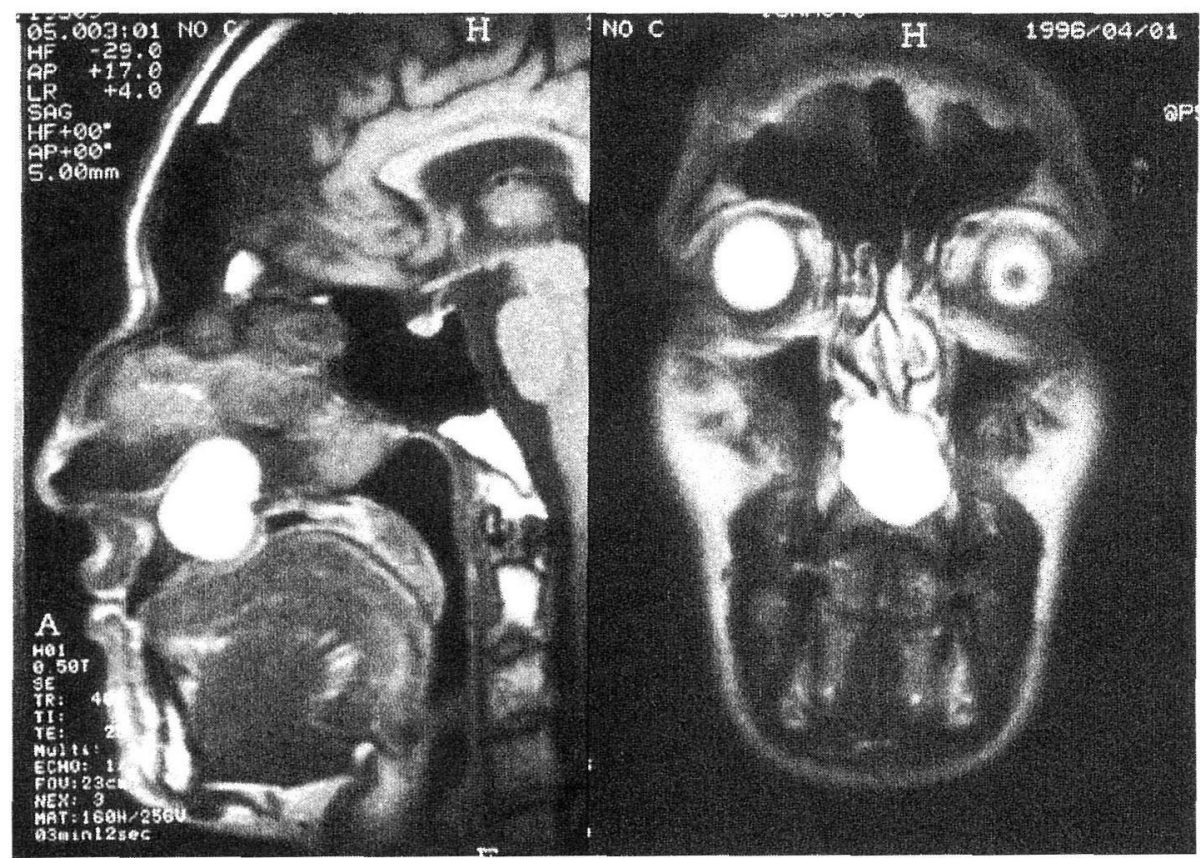

a

b

図 2 MRI 所見

T1，T2 強調ともに高信号を示す辺縁整の陰影を認め，蛋白濃度の高い液の貯留した 囊胞性病変が嶷われた。矢状断では口蓋骨鼻腔側の骨皮質の消失が，冠状断では鼻中 隔の欠損がみられる ( a : T1 矢状断 b : T2 冠状断). 

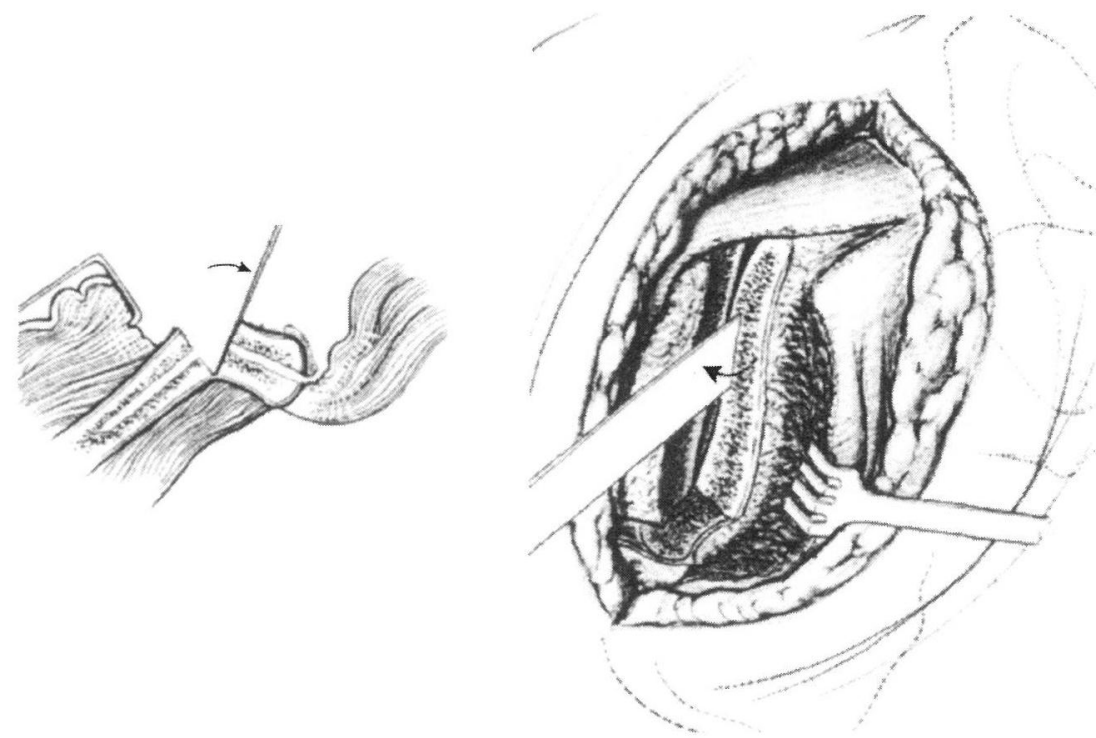

図 3 腸骨稜を扉状に開き，海綿骨を採取する．これを細かく砕いた後，フィブリ ン糊に混合して死空に充填した。

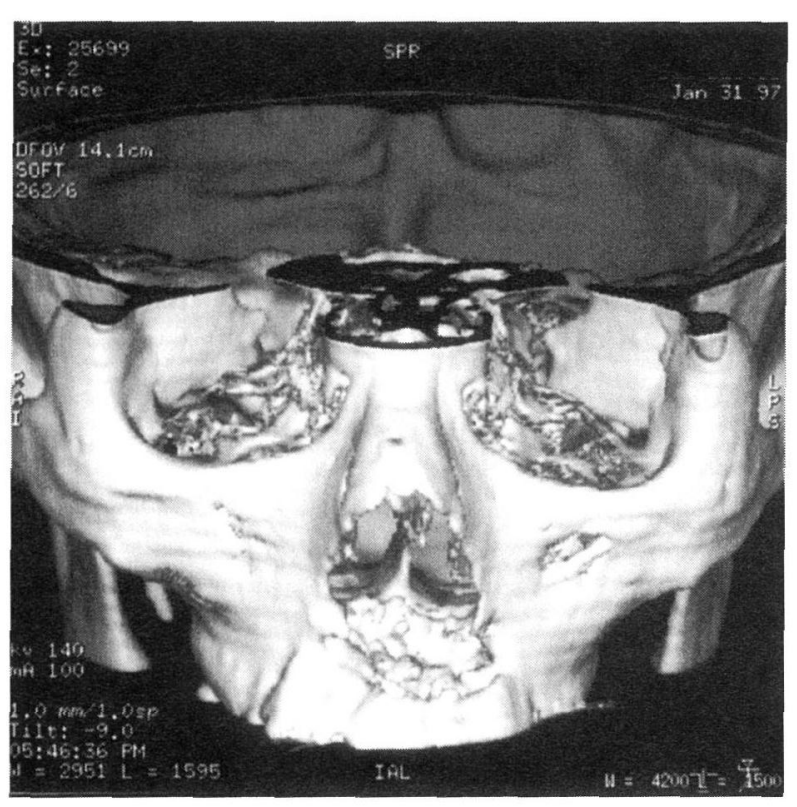

図 4 3D-CT 所見(術後 6 力月)

死腔を充填した海綿骨は骨化し，死腔を残すことなく周 囲の口蓋骨と適合している.

移植片の生着は良好で, 死腔を残すことなく良好に再建 されている。また 2 年 3 力月経過した現在も囊胞再発を 認めていない。

病理組織所見 : 囊胞の内壁は繊毛住上皮に被覆され,
周困には炎症性細胞が浸潤していた。その外層に線維性 結合織がみられ，鼻口蓋管囊胞と診断された(図 5 ).

\section{考察}

耳鼻咽喉科領域では上顎骨周囲に発生する賫胞性病変 として，鼻前庭囊胞吕多く経験される。しかし，上顎骨 に生じる囊胞の種類は多く，歯原性囊胞，顔裂性囊胞な ぞに分類される1)。鼻口蓋管囊胞は生後 1 年ほどの間, 存在する鼻口蓋管が消失する際に遺残した上皮から起こ る囊胞性病変で, 胎生期の顔面形成時の球状突起, 外側 鼻突起，上顎突起等の各突起の瘉合部に迷入した上皮か ら生じる鼻前庭囊胞, 正中口蓋囊胞, 球状上顎囊胞とは 区別される2).

その発生頻度は比較的まれで, Shear ${ }^{3)}$ は顎囊胞750例 中 89 例 $(11.9 \%)$, Killey $5^{4)}$ は翼胞性疾患の約 $5 \%$ で あったと報告している。本邦では，斉藤ら 患 255 例中 2 例 $(0.8 \%)$, 本田 $5^{6)}$ は4 44 例中 2 例 $(4.5 \%)$ であったと報告している．発現年齢は20歳以上で40歳前 後の高年㱓層に多いとされて扣り3), 性差についてはや や男性に多いという2)3).

病理組織学的所見は囊胞壁は上皮に被覆された結合織 からなり，この上皮は扁平上皮，移行上皮，立方上皮， 繊毛円柱上皮などさまざまで，1 種類のみであることは むしろ少ないとされる113。市た，粘液腺がみられると 

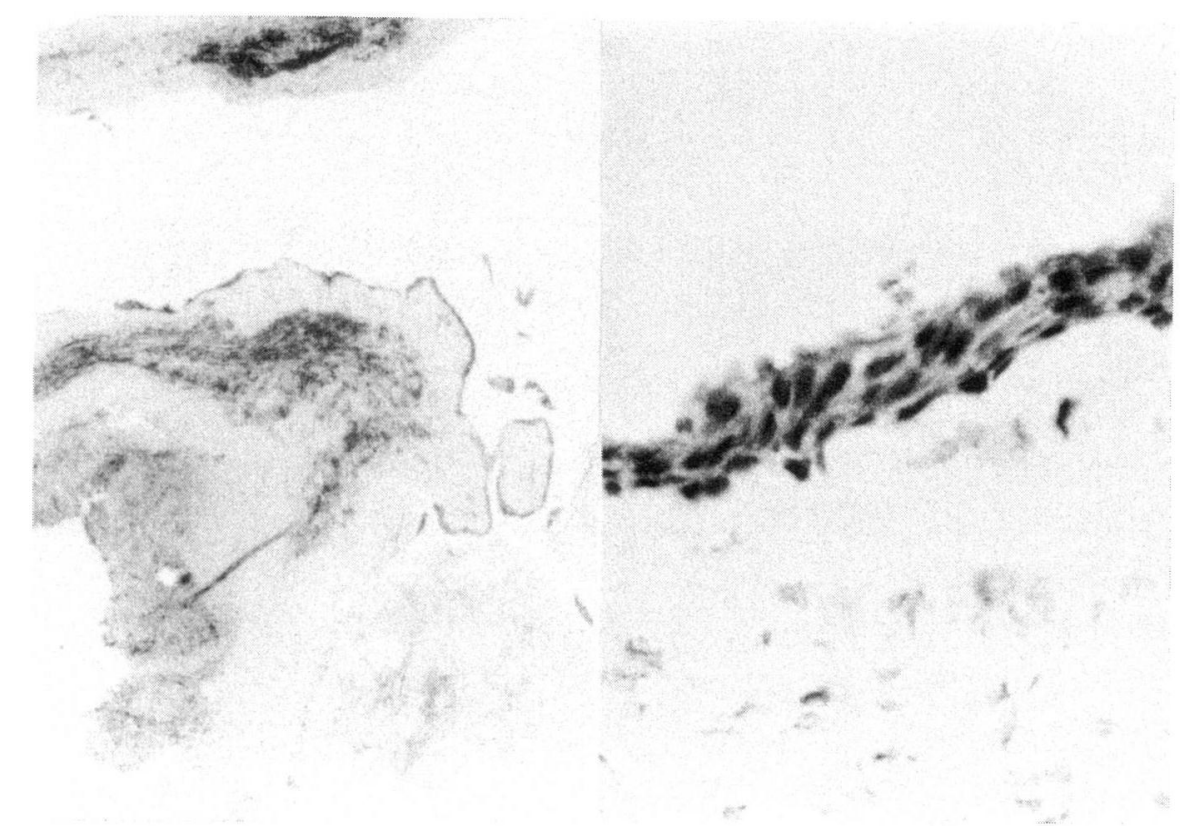

図 5 病理組織所見

内壁が䋐毛円柱上皮に被覆され，周囲には炎症性細胞の浸潤がみられる(HE 染 色 左: $\times 40$, 右: $\times 400)$.

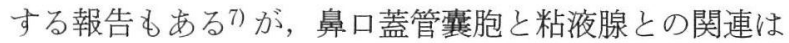
明らかではない，今回の症例では, 囊胞壁内層は瀻毛円 柱上皮からなり，外層の結合組織には神経組織がみられ たが，腺組織は明らかではなかった。

鼻口蓋管囊胞と鑑別すべき疾患としては，歯原性囊胞 や外傷性骨囊胞, 先に挙げた鼻前庭囊胞, 正中口蓋囊胞 や球状上龥囊胞などが挙げられる。自験例の場合, 歯牙 との関連がみられなかったことから歯原性襄胞とは鑑別 でき, 発生部位が上須前方の正中部であり, 鼻口蓋管を 中心に囊胞が広がっていたことから鼻前庭囊胞, 正中口 蓋襄胞や球状上罘襄胞とは鑑別され, 鼻口蓋管囊胞と診 断できた。

これまでの報告では, 摘出法に関して言及した報告2) はみられるが，その再建に関しての報告はみられない。

これは襄胞が大さいものでも最大径で $30 \mathrm{~mm}$ までと比 較的小さく，乙かも气の最大径は左右，あるいは前後方 向であるため218 10)，摘出後に大きな死腔を生じること がなかったためと考光られる、今回の症例では, 頭側と 尾側にも囊胞が拡大乙て叔り, このため充媜を要する死 腔を生じた。このような骨欠損を伴う部位の充填材料に は八イドロキシアパタイト, 自家皮質骨, 自家海綿骨な
ぞが考光られるが，鼻腔怙よびロ腔に近い部位で人工素 材を使用することは，感染の危険が大きく，自家骨が最 適と思われる。自家骨のなかでも, 皮質骨, 海綿骨単独, 両者の混合などの方法がある11) 13)が，感染に強くしか も比較的採取が容易で，必要に応じた採取量の調整や死 腔の形に合うょう形成しやすい海綿骨が最適であると考 党，自家腸骨海綿骨を死腔充填に用いた。今回の症例で は，術前にその大きさから腸骨から海綿骨を採取するこ とが予想されたため, インフォームドコンセントを行い 本人の理解を得た。従来の報告に批いても, 自家海綿骨, 特に腸骨の海綿骨は買裂の閉鎖などに多く利用され，信 頼性も高い素材である11) 13). 術後 6 力月と比較的早い 時点での 3D-CTでも，吸収されることなく周囲の骨と も良く適合して括り，また触診上も正常な硬口蓋と同様 であったことから，自家海綿骨による再建は有用である と考壳られた。

\section{結語}

比較的まれとされる鼻口蓋管襄胞を経験した。摘出後 の死腔の充填に腸骨からの自家海綿骨を使用し，良好な 結果を得た。 
なお，この論文の要旨は第61回耳鼻咽喉科臨床学会(1999年

6月26日)に拈いてロ演した.

\section{参考文献}

1）石川梧朗監修：鼻口蓋管襄胞. 口腔病理学 II. 371 388頁, 永末書店, 京都, 1984 .

2 ）高山泰男, 遠山良成, 松本光彦, 他: 鼻口蓋管囊胞の20例. 日口外誌 $34: 1444 \sim 1454,1988$.

3 ) Shear M : Nasopalatine duct cyst. Cysts of the Oral Regions (ed by Donald DD). pp 6, John Wright and Sons Ltd, Bristol, 1983.

4) Killey HC and Kay IW : Nasopalatine duct cyst. Benign Cystic Legions of the Jaws, Their Diagnosis and Treatment (ed by Robert B). pp 169 173, Churchill Livingstone, Edinburgh, 1977.

5 ）斉藤幸一, 四条誠一, 朝波惣一郎, 他 : 過去 5 年間に扣け る口腔領域囊胞性疾患の臨床統計的観察. 日口外誌 19 : 353 356, 1973.

6 ) 本田光徳, 須川 亮, 端山真次 : 大阪労災病院口腔外科開 設後10年間に打ける入院患者の臨床統計的観察. 日口外誌 $20: 347 \sim 353,1974$.

7 ）長田道哉, 増田元三郎, 石川好美, 他：結石を伴った切歯 管囊胞の 1 例. 日口外誌 $29: 1785 \sim 1983,1983$.
8 ) Swanson KS, Kaugars GE and Gunsolley JC : Nasopalatine duct cyst ; an analysis of 334 cases. J Oral Maxillofac Surg $49: 268 \sim 271,1991$.

9 ) Anneroth G, Hall G and Stuge U : Nasopalatine duct cyst. Int J Oral Maxillofac Surg $15: 572 \sim 580,1986$.

10) Hertzanu $Y$, Cohen $M$ and Mendelsohn DB : Nasopalatine duct cyst. Clin Radiol $36:$ 153 158, 1985.

11) Kortebein MJ, Nelson CL and Sadove AM : Retrospective analysis of 135 secondary alveolar cleft graft using iliac or calvarial bone. J Oral Maxillofac Surg 49:493 498, 1991.

12) Deams PN and Sotereanos GC : Closure of alveolar clefts with corticocancellous block grafts and marrow. J Oral Maxillofac Surg 46 : 682 687, 1988.

13) Kearns G, Perrott DH, Sharma A, et al : Placement of endosseous implants in grafted alveolar clefts. Cleft Palate Craniofac J 34 : 520 525, 1997.

$$
\left.\begin{array}{l}
\text { 原稿受付 : 平成 } 12 \text { 年 } 4 \text { 月 } 10 \text { 日 } \\
\text { 原稿採択 : 平成 } 12 \text { 年 } 5 \text { 月 } 24 \text { 日 } \\
\text { 別刷請求先 : 河田恭孝 } \\
\text { † } 632-8552 \text { 天理市三島町 } 200 \\
\text { 天理よろつ相談所病院耳鼻咽喉科 }
\end{array}\right)
$$

